\title{
Outcomes of vascular allograft transplants in the autonomous community of Catalonia, Spain
}

\author{
Resultados de los transplantes de aloinjertos vasculares en la comunidad autonoma de \\ Cataluña, España
}

Kerbi A. Guevara-Noriega ${ }^{1 *}$, Ma. Angelica Villamizar ${ }^{2}$, Juan G. Castro-Rios ${ }^{1}$, and Jose L. Pomar

${ }^{1}$ Department of Vascular Surgery, Parc Tauli University Hospital, Sabadell; '2Department of Anesthesiology, Hospital Santa Creu i Sant Pau, Barcelona; ${ }^{3}$ Department of Cardiovascular Surgery, Hospital Clinic i Provincial, Barcelona. Spain

\begin{abstract}
Background: The transplantation of tissues is a developing practice. Improving cryopreservation techniques and emerging of new immunobiology concepts have let to establish the transplant of vascular allografts as a suitable alternative. This study aims to expose the Catalan experience in vascular allograft transplantation by disclosing basic data about clinical outcomes. Materials and Methods: Data about vascular allografts transplants was gathered from the Registry of Vascular and Valvular Transplantation of Catalonia, Spain. Basic data regards to clinical outcomes are presented. Kaplan-Meier and statistical analysis were performed using SPSS Ver. 20 for Mac (Chicago USA). Results: One hundred and seventy-one adults were transplanted. The overall 5-year SR was 51.5\%. Survival (SR) differs with the territory revascularized, ranging from $37.5 \%$ to $55.6 \%$ at five years. Major adverse limb event-free rate ranges from $13.3 \%$ to $50.1 \%$ according to the area treated. The Primary patency rate is higher in the supra-inguinal revascularization and lowers when a distal vessel target is treated. Conclusion: Only one guideline-supported indication is currently done for allografts, and our results match with this indication. Our results are extensive and susceptible to analysis to address future projects, which are required to reconsider new or specific indications. More studies are needed to clarify the outcomes of arterial allografts.
\end{abstract}

Key words: Cryopreserved allografts. Major adverse limb event. Chronic limb-threatening ischemia. Vascular transplant. Vascular tissue.

\section{Resumen}

Antecedentes: El trasplante de tejido es una practica clínica en crecimiento. Las mejoras en técnicas de criopreservación y los nuevos conceptos sobre inmunobiología ha permitido que el trasplante vascular sea una alternativa a considerar. Este estudio expone la experiencia catalana en trasplante de tejido vascular mediante la exposición de datos clínicos. Materiales and Métodos: Los datos sobre trasplantes de aloinjertos vasculares se obtuvieron del Registro de trasplantes vasculares y valvulares de Cataluña, España (ReVAC). Se presentan datos básicos relacionados con los resultados clínicos. Kaplan Meier y el análisis estadístico se realizó con SPSS Ver. 20 para Mac (Chicago EE. UU.). Resultados: 171 adultos fueron trasplantados. La supervivencia a 5 años fue del 51,5\%. La supervivencia (SR) difiere con el territorio revascularizado, oscilando entre el $37,5 \%$ y el $55,6 \%$ a los cinco años. La tasa de sujetos libres de evento mayor en la extremidad (MALE-Free Rate) oscila entre el $13,3 \%$ y el 50,1\% según la zona tratada. La tasa de permeabilidad primaria es mayor en la revascular-

\footnotetext{
Correspondence:

*Kerbi A. Guevara-Noriega

Calle Bilbao 110, 8-6 Date of reception: 02-10-2020

C.P. 08018 , Barcelona, Spain Date of acceptance: 09-12-2020

E-mail: kerbiguevara@ hotmail.com

DOI: $10.24875 / C I R U .20001069$

Cir Cir. 2021;89(6):797-805

Contents available at PubMed

www.cirugiaycirujanos.com

0009-7411/@ 2020 Academia Mexicana de Cirugía. Published by Permanyer. This is an open access article under the terms of the CC BY-NC-ND license (http://creativecommons.org/licenses/by-nc-nd/4.0/).
} 
ización supra-inguinal y menor cuando se trata un vaso diana distal. Conclusión: En la actualidad, solo hay una indicación de trasplante de aloinjertos respaldada por las guías clínicas y nuestros resultados coinciden con esta indicación. Nuestros resultados son amplios y susceptibles de análisis para abordar proyectos futuros que se requieren para reconsiderar indicaciones nuevas o específicas. Se necesitan más estudios para aclarar los resultados de los aloinjertos arteriales.

Palabras clave: Aloinjertos criopreservados. MALE-Free rate. Isquemia crónica de extremidades inferiores. Trasplante vascular. Tejido vascular.

\section{Introduction}

The donation and transplantation of organs, tissues, and cells are, at present, going through a privileged moment. Thanks to the improving of cryopreservation techniques and arising of new concepts of immunobiology, some less popular practices such as tissue transplantation have evolved to become a common practice. In fact, transplantation of cryopreserved arterial allografts is accepted as a suitable alternative by American and European guidelines of Vascular Surgery ${ }^{1-3}$.

Nevertheless, behind this current acceptance different stages can be described for vascular allografts. The Nobel Prize in Medicine, Alexis Carrel, developed first projects in this field. Since then, a long way has been run. From the first steps, when publications of preliminary experiences and hopeful early results were showed, it was passed to abandonment due to the description of complications at medium- and longterm. At present, vascular allografts have been reconsidered for specific indications. This reconsideration of allografts, undoubtedly, was due to a better understanding of tolerance, as well as better immunopathology and conservation techniques ${ }^{1,4}$.

However, this resurfacing has been overshadowed by parallel-emerging technologies and techniques. In vascular surgery, endovascular techniques remain one of the most important choices when planning revascularization. Furthermore, we must also remember that autologous tissue in optimal conditions have been and will be over other types of graft because of its demonstrated superiority in term of patency rate and limb salvage rate'.

Moreover, in the absence of autologous grafts, prosthetics grafts still are the second-line resource in revascularization surgical procedures. That is why arterial allograft is limited to specific cases mainly because they are hard to obtain, to store and without benefits for the industry ${ }^{5}$. The indications of vascular allografts have been restricted to replacements of infected arterial prosthetics and on a lesser scale to replacements in complex arterial segments, complex vascular lesions, and vascular access for patients in hemodialysis. In fact, only one indication endorsed by guidelines and systematic reviews is the in-situ reconstruction of aorto-iliac territory in substitution of infected grafts ${ }^{2,3}$.

The Society for Vascular Surgery practice guidelines on the care of patients with an abdominal aortic aneurysm has recommended arterial allografts as an option of grafts and considered in-situ reconstruction with allografts as better than extra-anatomical revascularization techniques or the classical management, the complete graft excision followed by in-situ prosthetic reconstruction. European guidelines are more unspecific only clarifying that in-situ reconstructions with vascular allografts have a lower rate of adverse events that extra-anatomical bypass ${ }^{2,3}$. The origins of this practice date back to 1996. Koskas et al. documented six years of experience replacing infected prostheses from 83 cases with several postoperative complications, but with a limb survival rate of $100 \%$. After five years, Leseche et al. also commented on the usefulness of the use of vascular allografts in prosthetic infections ${ }^{6,7}$.

In addition, in 2004, the Parisian group of Kieffer published a large cohort. The replacement of infected grafts in the infrarenal aorta by vascular allografts was presented in a series conducted over 14 years. Kieffer et al. concluded that vascular allografts, in short as well as long-term are at least similar in behavior to other replacement techniques in terms of the management of infra-renal prosthesis infections. They also found that most of the complications associated with this type of grafts are avoidable with an adequate cryopreservation process. Similar results were exposed in Greece. Locati et al. published a short series of 18 patients where 25 infected prostheses were replaced in different areas such as femoropopliteal, aorto-iliac, and subclavian, concluding that these techniques are beneficial in this indication since these grafts seem to have more excellent resistance to infection ${ }^{8,9}$. 
The American experience was also exposed in the same order of ideas. In 2009, Brown et al. published their mid-term results for arterial reconstruction with cryopreserved vascular tissue in cases of prosthesis infections. They presented a series of 52 patients followed up over ten years that showed that the replacement of infected vascular prostheses by vascular allografts was a viable alternative. They stated that with adequate cryopreservation, allografts are resistant to reinfection, thrombosis and aneurysmal dilatation and recommended a long-term study to evaluate whether this technique is the most successful, effective and safe ${ }^{10}$. In the third stage (current stage) of the allografts, new trends in cryobiology and immunobiology exist, and the exact determinations of histocompatibility matching and safer immunosuppressive therapies have been reconsidered ${ }^{11}$. Nowadays, the problem lays in the lack of evidence in the correct behavior of allografts that, by being biologic tissue, are expected to act as a living structure with theoretical potential in the cardio-circulatory system. This lack of evidence is due to the trends to publish about prosthetic grafts because the allografts were ignored as a suitable alternative in their second age due to the described complications. Complications have been linked to poor conservation and cryopreservation techniques, and an immunologic response by the receptor.

Furthermore, a problem is the failure to identify the immune response related to the vascular, as well as, complications in a determined timeline and durability in the transplantation. Furthermore, there is a lack of scientific evidence in regarding the long-term outcomes, and emerging objective performance goals between allografts, autologous tissue or prosthetic materials, either Dacron or Polytetrafluorethylene (PTFE) that is the most common material used today.

\section{Methods}

We performed a retrospective analysis of the "Registry of vascular and valvular allografts transplant in the autonomous community of Catalonia, Spain (ReVAC)" which includes cases from 10 hospitals in the region of Catalonia, Spain. ReVAC includes cases from January 1995 to January 2014.

\section{Registry}

Data in the ReVAC are confidential. The registry is available through the website of the Catalonian
Government (Generalitat de Catalunya). Personal and digital data in Spain are protected according to the Organic Law for the protection of personal data and guarantee of digital rights (BOE-A-2018-16673). The review was conducted according to in-effect regulations and being respectful of the confidentiality of the patient information.

Due to the retrospective nature of this study, the follow-up was based on the examinations and visits recorded by the patient in his reference center. The monitoring was considered as ended at the date of the last visit to the vascular surgery department in the reference center, except for survival analysis that was used the last visit registered in any department or hospital in the autonomous community of Catalonia.

\section{Vascular allografts}

The vascular allografts distributed by the tissue banks of Catalonia are extracted in cases of multiorganic donation by centers authorized by the Catalan Organization of Transplantation. After their collection, allografts were transferred to the bank under sterile conditions and immersed in a preservation solution. In no case, the ischemia time was greater than $24 \mathrm{~h}$ (if the body has been refrigerated within the first $6 \mathrm{~h}$ since asystole) or greater than $12 \mathrm{~h}$ if the body has not been refrigerated.

Dissection and initial tissue evaluation were performed in laminar flow chambers under sterile techniques. In all the cases, a thorough inspection of the anatomical characteristics is, and all the grafts were immersed in a solution of cellular nutrient medium with antibiotics at the lowest effective concentration. They were kept under refrigeration for 12-30 h. A sample of vascular tissue is taken for pre-antibiotic microbiological control.

For cryopreservation, $10 \mathrm{ml} 143$ of dimethyl sulfoxide and $10 \%$ human albumin solution were used. The cryopreservation program used reduces the temperature of the tissues from $1^{\circ} \mathrm{C} / \mathrm{min}$ to a temperature of $-60^{\circ} \mathrm{C}$ and then from $3-4^{\circ} \mathrm{C} / \mathrm{min}$ to $-100^{\circ} \mathrm{C}$. The maximum programmed temperature deviations accepted was $10^{\circ} \mathrm{C}$. After reaching this temperature were extracted from the chamber and introduced into the vats of liquid nitrogen. There are control mechanisms that verify that the established parameters have been followed, periodically, tissues not used for clinical use were used with this intention. Storage is carried out in large capacity liquid nitrogen tanks monitored to maintain the proper level of liquid nitrogen. All tissues 
are validated 1 month after storage to be included in the bank's availability lists and distributed to hospitals on request.

When an implantation center needs an allograft, the tissue or tissues that best fit the request received are selected, and the information is prepared so that the implantation center can decide its acceptance. If the graft is accepted, the delivery is organized.

Before use, the grafts were thawed slowly in a sterile solution at $20^{\circ} \mathrm{C}$, and microbiological samples are taken before implantation. Senior vascular surgeons performed the surgery. In no case was immunosuppression or anticoagulation intentionally used after implantation. No distal vein patches were used in any case.

\section{End-points}

Our end-points were primary outcomes as primary patency, survival rate, limb salvage rate, as well as, objective performance goals as major limb adverse event-free (major adverse limb event [MALE]-free) rate.

\section{Definitions}

We considered infra-inguinal to any bypass with proximal anastomosis originating below the inguinal ligament. According to the nature of vascular three and know results, infra-inguinal was analyzed in two different groups: distal target vessel and femoropopliteal revascularization.

According to the objective performance goals for the lower extremity revascularization of the Society for Vascular surgery, we defined the MALE as any major amputation, major reintervention, including thrombectomy or bypass revision.

\section{Ethical statement}

Authors state that no human or animal experiments have been performed for this research, no patient data appear in this article. This project has been submitted to ethical evaluation which was carried out by the ethics committee of the "Hospital Clinic i Provincial de Barcelona." No funding sources.

\section{Statistical analysis}

Statistical analysis was performed using SPSS Ver. 20 for Mac (Chicago USA). The descriptive data are

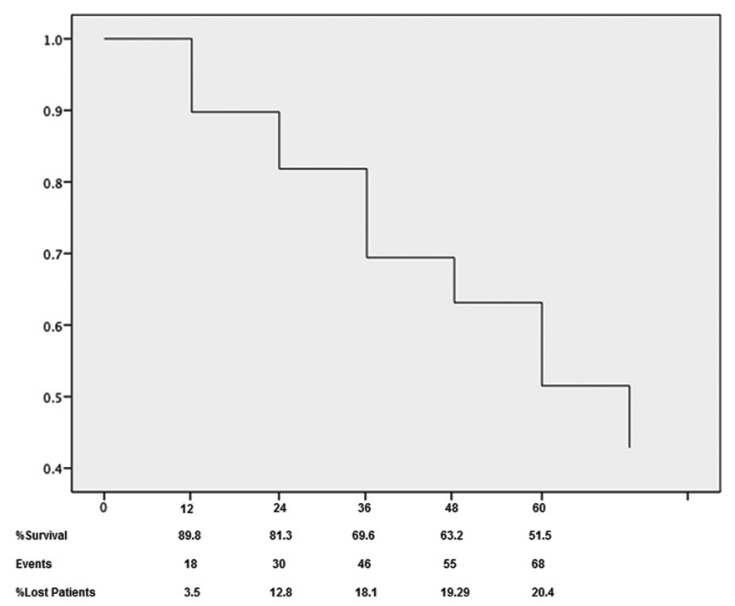

Figure 1. Survival rate of patients transplanted with arterial segments (Allografts).

presented in relative and/or absolute frequencies. Cumulative patient survival, limb salvage, patency rates, and MALE-free rates related to the patient were assessed by the Kaplan-Meier method. $\mathrm{P}<0.05$ level was used to determine statistical significance.

\section{Results}

A total of 171 adults were transplanted with a mean age of $69.1 \pm 11.08$ years whose $73.1 \%$ (125) were males. The surgery indication was chronic ischemia Grades III and IV of inferior extremities without autologous great saphenous veins available as conduit for the surgery in $77.2 \%$ (132) of the cases, infected prosthesis replacement or infected revascularization was the indication in $9.9 \%(17)$, previous allograft replacement represented $5.3 \%(9)$, and complex vascular lesion correction $3.5 \%$ (6). Other indications under surgeon criteria were performed in $4.1 \%$ of the patients.

Survival rate in adult patients with an arterial segment transplanted ranged from $89.8 \%$ to $51.5 \%$ as shown in figure 1 (Fig. 1).

Infra-inguinal revascularization was performed in $149(87.13 \%)$ patients and supra-inguinal in 15 (8.77\%). Other cases $(7: 4.1 \%)$ correspond to surgeries not involving the lower extremities. From those with infrainguinal revascularization, $108(72.5 \%)$ had a distal vessel anastomosis. Distal target vessel was the anterior tibial artery in $42(38.8 \%)$, peroneal artery $34(31.5 \%)$, posterior tibial artery $23(21.3 \%)$, tibialperoneal trunk $6(5.6 \%)$, and dorsalis pedis artery $3(2.8 \%)$ cases. 
A femoropopliteal bypass was performed in the remaining $41(27.5 \%)$ cases of infra-inguinal revascularization. From those with supra-inguinal revascularization, in $9(60 \%)$ cases an aorto-femoral revascularization was performed. $2(13.3 \%)$ iliac territory, and $1(6.7 \%)$ aortoplasty

\section{Results for supra-inguinal revascularization}

The survival rate for patients transplanted with arterial allografts in the supra-inguinal territory was $60 \%$ at 12 months and $37.5 \%$ at 60 months. 1-year and 5 -year MALE-Free rate was $40 \%$ and $13.3 \%$, respectively. Primary patency rates of the supra-inguinal allograft were $86.7 \%$ at 12 months and $72.2 \%$ at 60 months. Limb salvage rate has been yearly detailed in table 1 (Table 1).

\section{Results for infra-inguinal revascularization}

After 36 -month follow-up, more than $20 \%$ of patients transplanted with arterial allografts for femoropopliteal revascularization got lost. Only 1-year and 3-year rates are exposed. The survival rate for patients transplanted with arterial allografts in the femoropopliteal territory was $87.5 \% \%$ at 12 months and $75.1 \%$ at 36 months. 1-year and 3-year MALE-Free rate was $60.4 \%$ and $50.1 \%$, respectively. Primary patency rates of the femoropopliteal revascularization were $78.8 \%$ at 12 months and $64.8 \%$ at 36 months. Limb salvage rate was $83.4 \%$ at 36 months as shown in table 2 (Table 2).

When a distal target vessel revascularization was performed, the survival rate was $92.4 \%$ at 12 months and $55.6 \%$ at 60 months. 1-year and 5-year MALEFree rate was $52.5 \%$ and $18.2 \%$ respectively. Primary patency rates for distal target vessel revascularization with arterial allografts from $53.5 \%$ to $34.1 \%$ according to the cut-point. Limb salvage rate is exposed in table 3 (Table 3).

\section{Discussion}

Vascular allografts carry with a stigma from the adverse results observed in their first steps. Consequently, only a clear indication is covered by guidelines, the replacement of infected grafts in aortic position because after several series and publications, they have shown a lower reinfection rate and to be a
Table 1. Results of supra-inguinal revascularization with arterial allografts

\begin{tabular}{lccccc}
\hline Supra-inguinal & $\begin{array}{c}\mathbf{1 2} \\
\text { months }\end{array}$ & $\begin{array}{c}\mathbf{2 4} \\
\text { months }\end{array}$ & $\begin{array}{c}\mathbf{3 6} \\
\text { months }\end{array}$ & $\begin{array}{c}\mathbf{4 8} \\
\text { months }\end{array}$ & $\begin{array}{c}\mathbf{6 0} \\
\text { months }\end{array}$ \\
\hline Survival & $60 \%$ & $60 \%$ & $52.5 \%$ & $45 \%$ & $37.5 \%$ \\
Primary Patency & $86.7 \%$ & $72.2 \%$ & $72.2 \%$ & $72.2 \%$ & $72.2 \%$ \\
Limb Salvage & $93.3 \%$ & $93.3 \%$ & $93.3 \%$ & $93.3 \%$ & $62.2 \%$ \\
MALE-Free & $40 \%$ & $33.3 \%$ & $26.7 \%$ & $20 \%$ & $13.3 \%$ \\
\hline
\end{tabular}

Table 2. Results of femoropopliteal revascularization with arterial allografts

\begin{tabular}{lccc}
\hline Femoropopliteal & 12 months & 24 months & 36 months \\
\hline Survival & $87.5 \%$ & $78.8 \%$ & $75.1 \%$ \\
Primary Patency & $78.8 \%$ & $64.8 \%$ & $64.8 \%$ \\
Limb Salvage & $83.4 \%$ & $83.4 \%$ & $83.4 \%$ \\
MALE-Free & $60.4 \%$ & $54.2 \%$ & $50.1 \%$ \\
\hline
\end{tabular}

Table 3. Results of suprainguinal revascularization with arterial allografts

\begin{tabular}{lccccc}
\hline Distal Target V. & $\begin{array}{c}\mathbf{1 2} \\
\text { months }\end{array}$ & $\begin{array}{c}\mathbf{2 4} \\
\text { months }\end{array}$ & $\begin{array}{c}\mathbf{3 6} \\
\text { months }\end{array}$ & $\begin{array}{c}\mathbf{4 8} \\
\text { months }\end{array}$ & $\begin{array}{c}\mathbf{6 0} \\
\text { months }\end{array}$ \\
\hline Survival & $92.4 \%$ & $85.1 \%$ & $71.9 \%$ & $66.1 \%$ & $55.6 \%$ \\
Primary Patency & $53.5 \%$ & $42.5 \%$ & $39.2 \%$ & $36.9 \%$ & $34.1 \%$ \\
Limb Salvage & $59.5 \%$ & $49.3 \%$ & $46.1 \%$ & $46.1 \%$ & $43.4 \%$ \\
MALE-Free & $52.5 \%$ & $39 \%$ & $28.5 \%$ & $25 \%$ & $18.2 \%$ \\
\hline
\end{tabular}

reliable alternative. However, the first aspect to consider is that most of the unfortunate results of allografts were observed in other territories and indications ${ }^{1}$.

Recent publications have shown the role of the Natural Killer cells in the allograft rejection. The recently called "Allograft vasculopathy" has been linked to chronic inflammatory response mediated by Natural Killers. Furthermore, specific antibodies against the donor induce intracellular mechanisms that recruit monocytes and leukocytes injuring the transplanted tissue producing graft degeneration. The clinical expression of this mechanism could be occlusion, aneurysmal degeneration, and rupture ${ }^{12}$.

That is why despite this project involve cases out of the guideline-supported indication, the information 
provided must be carefully analyzed. In a new era where immunosuppressive therapy, ABO interaction, and antibodies mechanism of action can be analyzed and controlled, the clinical behavior showed previously by allografts in the past could be different in the current scenario.

The data showed in this research correspond to the transplant of arterial allograft without specific immunosuppression or control of these factors. Even so, the rates, which can be interpreted in any way, suggest that in some cases the arterial allografts made the work. Moreover, if we consider the hypotheses in which it is assumed that vascular allograft represents a viable alternative is because is a biologic tissue that behaves like the healthy autologous tissue and, additionally, we control that mentioned factors, arterial allografts could represent a reliable alternative. However, to the best of our knowledge, there are not publications involving arterial allografts and immunological factors control. Thus, the first step is to show results in large series like this and to incorporate the new performance gold standard in vascular surgery, as MALE rate.

It is essential to highlight that survival rates, as well as, patency, limb salvage, and MALE-free rates are linked to multiple factors regardless the grafts selected for revascularization, especially in the "vascular patient," and therefore, some comparison between grafts must be made. We exposed results of arterial allograft in the supra-inguinal territory where few publications are published, none of them with MALE-free rate as an endpoint. For femoropopliteal and distal target vessel revascularization, the known primary patency rate of PTFE, the most commonly used graft, is around $51 \%$ and $25 \%$, respectively. If we compare this result with our $43 \%$ and $34 \%$, at least more extensive studies are justified ${ }^{13}$. From a different point of view, regarding to the supra-inguinal territory, where the primary indication is the infected prosthesis replacement, primary patency at 5 years in our cohort $(72,2 \%)$ resembles the one observed in the superficial femoral vein reconstruction also called Neoaortoiliiac System (NAIS) in which the primary patency at 5 years is close to $75 \%$, making allograft a viable alternative. However, as it was previously exposed, this already is an indication supported by the European Society of Vascular Surgery Guideline ${ }^{2,14}$.

Moreover, the axilo-femoral bypass has a 5 -year patency rate of $55 \%$ approximately for the bifemoral technique and $14 \%$ for the unifemoral technique according to the New England Cardiovascular Surgery
Society. The summary is that extra-anatomic surgery is not better than arterial allograft in this territory. Nevertheless, extra-anatomic still have some indications because it is a less invasive technique useful in very complex and comorbid patients ${ }^{15,16}$.

However, not only primary patency matter but also survival and infection rate must be considered in infected aortic graft replacement. Kieffer et al. showed that allografts have a considerable annual mortality rate reduction compared to another type of grafts and its use is limited due to the availability of tissue. Arterial allograft has been shown that has the lowest reinfection rates only being overcome by NAIS ${ }^{8}$.

Regarding the Limb Salvage rate, Allograft and NAIS represented the best alternative with lower amputation rate and mortality according to Smeds et al. when compared different therapeutic options in infected prostheses. Other publications have reinforced the use of allografts or NAIS in front of extra-anatomical revascularizations due to a better limb salvage rate $^{16-18}$. Regarding the infra-inguinal revascularization, it is known that while more distal the anastomosis, less primary patency. Therefore, it is necessary to differentiate the allograft used in the femoral-popliteal with the ones with distal vessel anastomosis. In patients with critical limb ischemia and distal vessel target revascularization, our results demonstrated 5 -year primary patency similar to PTFE $(34 \%$ allografts vs. $25 \%$ PTFE). We can consider that factors affecting result could determine outcomes regardless of the graft used. However, more studies controlling immunological factors are justified. For limb salvage and MALE-free rate comparison, there are not comparable cohorts to extract valid conclusions ${ }^{19,20}$.

MALE is a current objective performance goal. In our cohort, it is important to highlight that after five years between $81.2 \%$ and $86.7 \%$ (according to the revascularized territory) of our patients presented a MALE. At first sight, this could be discouraging. However, due to the complexity of the so-called "vascular patient" and their multiple systemic comorbidities, these results are according to the expected evolution. Dead cause and future analysis should be researched in future publications. Our team has previously focus in this specific endpoint ${ }^{21,22}$. A direct comparison between grafts is considered incorrect because of several factors affecting the outcomes. Anticoagulation, antiaggregating therapy, medical history of patients, groups selected for analysis, exclusion de specific group of patients, and etcetera could affect the final results of any cohort. However, 
Table 4. Allografts versus other grafts: primary patency

\begin{tabular}{|c|c|c|c|c|c|c|c|c|}
\hline \multicolumn{9}{|c|}{ Primary Patency } \\
\hline Author & Year & Graft & Territory & 1 year & 2 year & 3 year & 4 year & 5 year \\
\hline Guevara-Noriega & 2019 & Allografts & Suprainguinal & 87 & 72 & 72 & 72 & 72 \\
\hline Jackson & 2000 & Autologous Vein & Femoro-Popliteal & 78 & 71 & 58 & 58 & - \\
\hline Gwan-Chul & 2012 & Dacron & Suprainguinal & - & - & - & - & 86 \\
\hline Prager & 2003 & Dacron & Suprainguinal & - & - & - & - & 89 \\
\hline Jonhson & 1999 & Dacron & Extra-Anatomical & 79 & - & 63 & - & 50 \\
\hline Prager & 2003 & PTFE & Suprainguinal & - & - & - & - & 88 \\
\hline Jonhson & 1999 & PTFE & Extra-Anatomical & 77 & - & 62 & - & 47 \\
\hline Guevara-Noriega & 2019 & Allografts & Femoro-Popliteal & 79 & 65 & 65 & - & - \\
\hline Suckow & 2013 & Autologous Vein & Femoro-Popliteal & 70 & - & - & - & - \\
\hline Devine & 2004 & Dacron & Femoro-Popliteal & 71 & - & 54 & - & 46 \\
\hline Daenens & 2009 & PTFE-Heparine & Femoro-Popliteal & 92 & 83 & - & - & - \\
\hline Devine & 2004 & PTFE & Femoro-Popliteal & 62 & - & 44 & - & 35 \\
\hline Jackson & 2000 & PTFE & Femoro-Popliteal & 58 & 47 & 36 & 32 & \\
\hline Guevara-Noriega & 2019 & Allografts & Distal Vessel & 54 & 43 & 39 & 37 & 34 \\
\hline Avgerinos & 2015 & Autologous Vein & Distal Vessel & & 47 & & & 32 \\
\hline Suckow & 2013 & Autologous Vein & Distal Vessel & 72 & - & - & - & - \\
\hline Avgerinos & 2015 & Alternative Vein & Distal Vessel & & 24 & & & 23 \\
\hline Furuyama & 2018 & PTFE & Distal Vessel & 75 & 65 & 60 & - & - \\
\hline Avgerinos & 2015 & PTFE & Distal Vessel & & 43 & & & 38 \\
\hline
\end{tabular}

Table 5. Allografts versus other grafts: major adverse limb event-free rate

\begin{tabular}{|c|c|c|c|c|c|c|c|c|}
\hline \multicolumn{9}{|c|}{ Major Adverse Limb Events-Free Rate } \\
\hline Author & Yr. & Graft & Territory & 1 year & 2 year & 3 year & 4 year & 5 year \\
\hline Guevara-Noriega & 2019 & Allografts & Suprainguinal & 40 & 33 & 26 & 20 & 13 \\
\hline Guevara-Noriega & 2019 & Allografts & Femoro-Popliteal & 60 & 54 & 50 & - & - \\
\hline Tsujimura & 2019 & Endovascular & Femoro-Popliteal & 82 & - & - & - & - \\
\hline Uhl & 2017 & Autologous Vein & Femoro-Popliteal & 76 & - & 72 & - & 69 \\
\hline Uhl & 2017 & Heparine PTFE & Femoro-Popliteal & 74 & - & 64 & - & 55 \\
\hline Guevara-Noriega & 2019 & Allografts & Distal Vessel & 53 & 39 & 29 & 25 & 18 \\
\hline Ziza & 2015 & Venous Allograft & Distal Vessel & 65 & - & 43 & - & 28 \\
\hline
\end{tabular}

a simple comparison of ratios could be exposed, but a more in-depth analysis is required in other to extract conclusions.
In 2011, Ziegler et al. published a compilation of reported data about primary outcomes of several types of grafts. In this review cases of reinterventions 
Table 6. Allografts versus other grafts: limb salvage rate

\begin{tabular}{|c|c|c|c|c|c|c|c|c|}
\hline \multicolumn{9}{|c|}{ Limb Salvage Rate } \\
\hline Author & Year & Graft & Territory & 1 year & 2 year & 3 year & 4 year & 5 year \\
\hline Guevara-Noriega & 2019 & Allografts & Suprainguinal & 93 & 93 & 93 & 93 & 62 \\
\hline Guevara-Noriega & 2019 & Allografts & Femoro-Popliteal & 83 & 83 & 83 & - & - \\
\hline Uhl & 2017 & Autologous Vein & Femoro-Popliteal & 78 & - & 57 & - & 48 \\
\hline Uhl & 2017 & Heparine PTFE & Femoro-Popliteal & 74 & - & 51 & - & 28 \\
\hline Jackson & 2000 & PTFE & Femoro-popliteal & - & - & - & 56 & - \\
\hline Guevara-Noriega & 2019 & Allografts & Distal Vessel Target & 60 & 49 & 46 & 46 & 43 \\
\hline Suckow & 2013 & Autologous Vein & Distal Vessel Target & 86 & - & - & - & - \\
\hline Ziza & 2015 & Venous Allograft & Distal Vessel Target & 83 & - & 70 & - & 53 \\
\hline Harris & 2001 & Allografts & Distal Vessel Target & 66 & - & 62 & - & - \\
\hline Stonebridge & 2000 & PTFE & Distal Vessel Target & 53 & 44 & - & - & - \\
\hline
\end{tabular}

were excluded. From these data, and the publications analyzed during the writing of this manuscript, a comparative table of allografts versus other vascular grafts has been built (Tables 4-6).

\section{Conclusion}

Survival, primary patency, limb salvage, and MALE-free rates have been analyzed for arterial segments in supra-inguinal and infra-inguinal revascularization. Results are extensive and susceptible to analysis.

Only one guideline-supported indication is currently done for allografts, the replacement of infected aortic grafts. However, information about lower extremities revascularization is useful to address future project, which is required to reconsider new or specific indications. Cryopreserved and surgical techniques are determinants in the global survival rate in valvular allograft transplants. Hemodynamic changes are expected complications of a valvular allograft. However, these changes do not traduce in mortality, and the overall survival rate is reasonable. Lack of availability, costs and surgeon preferences could be a determinant factor in the limitation of this practice. Even though, favorable results indicate that valvular allograft transplant is a good alternative. Our group considers that its use should be done according to each patient needs.

\section{Acknowledgments}

The workgroup gratefully acknowledges the support given by Catalan Organization of Transplants and Hospital Clinic I Provincial Barcelona.

\section{Conflicts of interest}

The authors declare that there are no conflicts of interest.

\section{Funding}

The authors declare that there is no funding in this research.

\section{Responsabilidades éticas}

Protección de personas y animales. Los autores declaran que los procedimientos seguidos se conformaron a las normas éticas del comité de experimentación humana responsable y de acuerdo con la Asociación Médica Mundial y la Declaración de Helsinki.

Confidencialidad de los datos. Los autores declaran que han seguido los protocolos de su centro de trabajo sobre la publicación de datos de pacientes.

Derecho a la privacidad y consentimiento informado. Los autores han obtenido el consentimiento 
informado de los pacientes y/o sujetos referidos en el artículo. Este documento obra en poder del autor de correspondencia.

\section{References}

1. Guevara-Noriega KA, Martinez A, Alvarez B, Pomar JL. Historical overview of vascular allografts transplantation. Vasc Endovasc Rev. 2019;2:19-22.

2. Wanhainen A, Verzini F, Van Herzeele I, Allaire E, Bown M, Cohnert T, et al. European society for vascular surgery (ESVS) 2019 clinical practice guidelines on the management of abdominal aorto-iliac artery aneurysms. Eur J Vasc Endovasc Surg. 2019;57:8-93.

3. Chaikof EL, Dalman RL, Eskandari MK, Jackson BM, Lee WA Mansour MA, et al. The society for vascular surgery practice guidelines on the care of patients with an abdominal aortic aneurysm. J Vasc Surg. 2018;67:2-77.

4. Ferrer A, Socarrás N, Del Risco T, Gomez J, Ruiz A. Trasplante de tejido vascular. Recuento histórico y utilización clínica. AMC. 2005;9:128-35.

5. Twine CP, McLain AD. Graft type for femoro-popliteal bypass surgery. Cochrane Database Syst Rev. 2010;5:CD001487.

6. Koskas F, Plissonnier D, Bahnini A, Ruotolo C, Kieffer E. In situ arterial allografting for aortoiliac graft infection: a 6-year experience. Cardiovascular Surg. 1996;4:495-9.

7. Leseche G, Castier Y, Petit MD, Bertrand P, Kitzis M, Mussot S, et al. Long-term results of cryopreserved arterial allograft reconstruction in infected prosthetic grafts and mycotic aneurysms of the abdominal aorta. J Vasc Surg. 2001;34:616-22.

8. Kieffer E, Gomes D, Chiche L, Fleron MH, Koskas F, Bahnini A. Allograft replacement for infrarenal aortic graft infection: early and late results in 179 patients. J Vasc Surg. 2004;39:1009-17.

9. Locati PM, Gallo E, Constantin E, Campanati B, Socrate AM, Lanza G, et al. The use of allografts in the surgical treatment of patients with infected vascular prostheses. Vestn Khir Im I I Grek. 1998;157:103-6.
10. Brown KE, Heyer K, Rodriguez H, Eskandari MK, Pearce W, Morasch MD. Arterial reconstruction with cryopreserved human allografts in the setting of infection: a single-center experience with midterm follow-up. $\mathrm{J}$ Vasc Surg. 2009;49:660-6.

11. Mestres C. Homoinjertos vasculares. In: Revuelta JM, editor. Avances en Cirugía de la Aorta. Barcelona: Ediciones Uriach, Barcelona; 2004. p. 136-51.

12. Merola J, Jane-Wit DD, Pober JS. Recent advances in allograft vasculopathy. Curr Opin Organ Transplant. 2017;22:1-7.

13. Ziegler KR, Muto A, Eghbalieh S, Dardik A. Basic data related to surgical infrainguinal revascularization procedures: a twenty year update. Ann Vasc Surg. 2011;25:413-22.

14. Treska V, Certik B, Molacek J. Management of aortic graft infections-the present strategy and future perspectives. Bratisl Lek Listy. 2016;117:125-32.

15. Johnson WC, Squires JW. Axillo-femoral (PTFE) and infrainguinal revascularization (PTFE and umbilical vein). Vascular registry of the New England society for vascular surgery. J Cardiovascular Surg. 1991;32:344-9.

16. Eggli S, Von Flue M, Vogt B. Axillo-femoral bypass: indications and results. Helv Chr Acta. 1992;59:307-9.

17. Smeds MR, Duncan AA, Harlander-Locke MP, Lawrence PF, Lyden S, Fatima J, et al. Treatment and outcomes of aortic endograft infection. $\mathrm{J}$ Vasc Surg. 2016;63:332-40

18. Akhtar M, Meecham L, Birkett R, Pherwani AD, Fairhead JF. Conservative treatment of an infected aortic graft with antibiotic irrigation. Int $J$ Angiol. 2016;25:e118-20.

19. van Reedt Dortland RW, van Leeuwen MS, Steijling JJ, Theodorides T, van Vroonhoven TJ. Long-term results with vein homograft in femoro-distal arterial reconstructions. Eur J Vasc Surg. 1991;5:557-64.

20. Johnson WC, Lee KK. A comparative evaluation of polytetrafluoroethylene, umbilical vein, and saphenous vein bypass grafts for femoral-popliteal above-knee revascularization: a prospective randomized department of veterans affairs cooperative study. J Vasc Surg. 2000;32:268-77.

21. Guevara-Noriega KA, Lucar GA, Pomar JL. Cryopreserved allografts for treatment of chronic limb-threatening ischemia in patients without autologous saphenous veins. Ann Vasc Surg. 2019;60:379-87.

22. Guevara-Noriega KA, Armstrong V, Bejarano M, Sosa C, Riera C, Lopez $\mathrm{P}$, et al. Registry of valvular and vascular allograft transplants in the autonomous community of Catalonia, Spain (ReVAC): design of the registry. Transplant Proc. 2020;52:360-4. 